\title{
Aturan Pembebasan Narapidana dengan Program Asimilasi dan Integrasi di Tengah Wabah Covid-19 di Tinjau Dari Peraturan Menteri Hukum dan Ham Nomor 10 Tahun
} 2020

\author{
Halim Dimas Ferdiansyah ${ }^{1}$ \\ Universitas Trunojoyo Madura \\ 160111100129@student.trunojoyo.ac.id \\ Syamsul Fatoni ${ }^{2}$ \\ Universitas Trunojoyo Madura
}

\begin{abstract}
ABSTRAK
Dasar pertimbangan dikeluarkannya Peraturan Menteri Hukum dan Hak Asasi Manusia Nomor 10 Tahun 2020 tentang Persyaratan Pemberian Hak Asimilasi dan Integrasi bagi Narapidana dan Anak dalam rangka pencegahan dan penanggulangan penyebaran COVID-19. dengan banyaknya tingkat hunian di penjara, hal ini telah menimbulkan kekhawatiran bagi pemerintah. Namun, terpidana yang dibebaskan mengulangi kejahatannya lagi dan menimbulkan kecemasan publik. Tujuan dari penelitian ini adalah untuk mengetahui perbedaan antara Permenkumham Nomor 3 Tahun 2018 dengan Permenkumham Nomor 20 Tahun 2020 dan kesesuaian prinsip pembinaan dengan Undang-Undang Nomor 12 Tahun 1995 tentang pemasyarakatan. Metode yang digunakan dalam penelitian ini adalah penelitian hukum normatif dengan menggunakan pendekatan perundang-undangan, pendekatan konseptual. Hasil penelitian ini menunjukkan bahwa perbedaan pemberian hak asimilasi dan integrasi narapidana dalam Permenkumham Nomor 3 Tahun 2018 diberikan sesuai dengan persyaratan substantif dan administratif secara lengkap. Namun dalam Permenkuham Nomor 10 Tahun 2020 terdapat beberapa perbedaan dalam hal pemberian hak asimilasi dan integrasi, baik persyaratan substantif maupun administratif, sehingga Permenkumham Nomor 10 Tahun 2020 memudahkan narapidana mendapatkan hak asimilasi dan integrasi. serta pelaksanaan ketentuan pemberian asimilasi dan integrasi dalam Permenkumham Nomor 10 Tahun 2020 tidak sesuai dengan prinsip pembinaan dalam undang-undang pemasyarakatan. Ketidaksesuaian tersebut dikarenakan adanya narapidana yang kembali melakukan tindak pidana, hal ini menunjukkan kegagalan dalam melakukan pembinaan terhadap narapidana. Pasalnya, program pembebasan hanya berfokus pada pencegahan penularan COVID-19 di lapas
\end{abstract}

Kata kunci: asimilasi, integrasi, narapidana, perbedaan dan kesesuaian Permenkumham

\section{ABSTRACT}

The basis for the consideration of the issuance of Regulation of the Minister of Law and Human Rights Number 10 of 2020 concerning the Requirements for Granting Assimilation and Integration Rights for Prisoners and Children in the context of preventing and overcoming the spread of COVID-19. with many occupancy rates in prisons, it caused a concern of the government. However, the convict who was released repeated the crime again and caused public anxiety. The purpose of this research was to find out the difference between Permenkumham (Regulation of the minister of Law and human righs) Number 3 of 2018 and Permenkumham Number 20 of 2020 and the suitability of the principles of development with Law Number 12 of 1995 concerning correctionalism. The method used in this research was a type of normative legal research using a statutory approach, a conceptual approach. The results of this study indicated that the differences in the provision of assimilation rights and integration of prisoners in Permenkumham No.3 of 2018 were given in accordance with the complete substantive and administrative requirements. However, in Permenkuham No.10 of 2020 there are several differences in terms of granting assimilation and integration rights, both substantive and administrative requirements, so that Permenkumham No.10 of 2020 made it easier for inmates to get the right of assimilation and integration. and the implementation of the provisions for assimilation and integration in Permenkumham No.10 of 2020 is not in accordance with the principles of guidance in the correctional law. This mismatch was due to the presence of prisoners who had returned to committing criminal acts, this indicated a failure to provide guidance to prisoners. This was because the release program only focuses on preventing transmisfsion of COVID-19 in prisons.

Keywords: Assimilation, Integration, Prisoners, Differences and suitability of Permenkumham 


\section{PENDAHULUAN}

Peristilahan sistem peradilan pidana mengacu pada proses terdiri dari lembaga kepolisian dalam masyarakat untuk mengatasi kejahatan. Jaksa pidana, pengadilan dan lembaga pemasyarakatan.1 Aparat penegak hukum memiliki kewenangan yang diberikan oleh hukum untuk menjalankan proses peradilan pidana. Teori sistem dalam sistem peradilan pidana yaitu tahapan penyidikan, penuntutan, peninjauan kembali pengadilan, dan tingkat pelaksanaan atau pemidanaan putusan.2

Lembaga pemasyarakatan adalah tempat yang memberikan pembinaan kepada narapidana yang akan diterima dengan keterampilannya setelah keluar dari Lapas. Narapidana bukan hanya obyek, tetapi juga subyek seperti orang lain yang melakukan kesalahan, dan mereka yang melakukan kesalahan akan dihukum. Pasal 1 UndangUndang Nomor 12 Tahun 1995 tentang Lembaga Pemasyarakatan menjelaskan tentang "Pemasyarakatan adalah kegiatan yang membina warga binaan di lembaga pemasyarakatan berdasarkan bagian terakhir dari sistem pidana dalam sistem peradilan pidana, yaitu sistem, kelembagaan, dan tata cara pembinaan".

Tujuan dari sistem pemasyarakatan adalah untuk meningkatkan kualitas narapidana, membuat mereka sadar akan

\footnotetext{
1Romli Atmasasmita, Sistem Peradilan Pidana Perspektif Eksistensialisme Dan Abolisionalisme, Penerbit Bina Cipta, Jakarta, 1996, Hlm. 15.

${ }^{2}$ Muhammad abdul fatah f, "Pelaksanaan hukuman cambuk di dalam lembaga pemasyarakatan di tinjau dari tujuan pemasyarakatan", universitass trunojoyo madura, tahun $2020 \mathrm{hlm} .1$
}

kesalahan mereka, meningkatkan kualitas mereka sendiri dan menghindari pelanggaran berulang sehingga mereka dapat diterima di masyarakat serta dapat hidup dengan warga yang bertanggung jawab. Berdasarkan Undang-Undang No 12 tahun 1995 tentang pemasyarakatan, pembinaan narapidana harus susuai asas yang berlaku di LAPAS:

1. Pengayoman

2. Pesamaan perlakuan dan pelayanan

3. Pendidikan

4. Pembimbingan

5. Penghormatan harkan dan martabat manusia

6. Kehilangan kemerdekaan merupakan satu satunya penderitaan, dan

7. Terjaminnya hak untuk tetap berhubungan dengan keluarga dan orangorang tertentu

Proses pembinaan harus memiliki fasilitas yang memadai, namun kenyataannya tempat pembinaan atau LAPAS saat ini mengalami peningkatan jumlah narapidana yang berakibat pada kelebihan kapasitas. Hal tersebut tidak sesuai dengan tujuan lembaga pemasyarakatan dimana terdapat hak bagi narapidana yang dijatuhi sanksi pidana sesuai dengan yang telah dilakukan, sebagaimana dituankan pada Pasal 14 Undang-Undang Nomor 12 tahun 1995 tentang lembaga pemasyarakatan, yaitu:

1. Ibadah menurut agama atau kepercayaan;

2. Memperoleh Menerima perawatan mental dan fisik;

3. Menerima pendidikan dan pengajaran;

4. Memperoleh pelayanan kesehatan dan makanan yang layak; 
5. Mengajukan keluhan;

6. Memperoleh bahan bacaan dan memperhatikan siaran media massa lain yang tidak dilarang;

7. Memperoleh gaji atau uang asuransi untuk pekerjaan yang Anda lakukan;

8. Menerima kunjungan dari anggota keluarga, penasihat hukum atau orang tertentu lainnya;

9. Mengurangi kalimat (lega);

10. Memperoleh kesempatan untuk asimilasi, termasuk liburan mengunjungi kerabat;

11. Pembebasan Bersyarat;

12. Meminta cuti sebelum bebas; dan

13. Memperoleh hak lain sesuai dengan hukum dan peraturan saat ini.

Selain hak narapidana diatur dalam Pasal 14 Undang-Undang No 12 Tahun 1995, Undang-Undang Nomor 03 Tahun 2018 Menteri Hukum dan HAM juga mengatur ketentuan dan prosedur remisi, asimilasi, kunjungan keluarga, dan pembebasan bersyarat.

Sementara itu, saat musim pandemi COVID-19, Kementerian Hukum dan HAM akan membebaskan kurang lebih sekitar 30.000 tahanan dewasa dan anak dari penjara, Rutan Negara, dan Lembaga Pembinaan Anak (LPKA) khusus dengan menerbitkan Peraturan dan Keputusan Menteri. Dalam Perpres tersebut menjelaskan salah satu pertimbangan untuk pembebasan narapidana adalah tingginya tingkat hunian Lapas atau bisa dikatakan overcrowded membuat rentan terhadap penyebaran Covid-19.3 Ada juga

3 Kompas.com, “Pembebasan 30.000 Narapidana Akibat Wabah Virus Corona" di kekhawatiran bahwa tingkat hunian yang berlebihan dapat menjadi target virus Covid19 untuk dengan mudah mereplikasi dan menginfeksi satu sama lain. Selain itu, pemerintah pun mengaku menghemat biaya sebesar Rp. 260 miliar program hak asimilasi dan integrasi untuk kurang lebih sekitar 30.000 tahanan ini. 4

Kelebihan kapasitas menjadi penyebab penyebaran Covid-19 dan atas dasar kemanusiaan, perlu dilakukan program asimilasi dan hak integrasi bagi orang tua, perempuan dan anak. Berdasarkan data sistem basis data pemasyarakatan yang diperbarui pada 13 April 2020, dari 33 kantor wilayah. Kapasitas keseluruhan 132.335 sedangkan total narapidana 61.326 dan total narapidana 175.440 sehingga total narapidana dan narapidana berjumlah 236.776 tetapi overcapacity mencapai $236.676-132.335=$ 104.441 sehingga overcapacity mencapai 105\%. Sebanyak 35.676 orang yang mendapatkan kebijakan pembebasan dengan program asimilasi dan hak integrasi.5

Menurut Undang-Undang Republik Indonesia Nomor 6 tahun 2018 tentang Karantina adalah "Membatasi kegiatan dan / atau karantina penderita penyakit menular sesuai dengan ketentuan peraturan perundangundangan, walaupun tidak menunjukkan

kutipdari https://nasional. kompas.com/ read/2020/04/01/09314561/pembebasan-30000narapidana-akibat-wabah-virus-corona. (diaksess pada tanggal 03 Juni 2020)

4 Utang Rosidin. Dkk, Kebijakan Asimilasi dan Hak Integrasi Narapidana di Tengah Pandemi COVID-19 Persfektif Hukum Penitensier Universitas Islam Negeri Sunan Gunung Djati, Bandung, tahun 2020, hlm 1

5 Sistem Data base Pemasyarakatan http://smslap.ditjenpas.go.id/public/grl/current/m onthly (diakses pada tanggal 13 april 2020) 
gejala apapun atau sedang dalam masa inkubasi, dan mengandung barang yang menyebabkan penyakit atau sumber pencemaran lain untuk mencegah kemungkinan penularan ke orang terdekat dan item".6

Diktum Keputusan Menteri Hukum dan HAM berbunyi "bahwa untuk melakukan upaya menyelamatkan terhadap narapidana dan anak yang berada di lembaga pemasyarakatan ,lembaga pembinaan khusus anak, dan rumah tahanan negara, maka perlu dilakukan pengeluaran dan pembebassan melalui asimilasi dan integrasi dalam rangka pencegahan dan penanggulangan penyebaran Covid-19".7 Pembebasan singkat narapidana juga dapat menjadi jaminan bagi pemerintah atas hak hidup narapidana pada kondisi pandemi, seperti sebagaimana diatur dalam Pasal 4 Undang-Undang Nomor 39 Tahun 1999 tentang HAM yakni menekankan frase hak untuk hidup dan hak asasi manusia yang tidak dapat dibatasi dalam keadaan apapun. 8

Pemerintah Indonesia membebaskan narapidana melalui dua program, yaitu program asimilasi dan integrasi. Menurut Pasal 1 ayat 3 Menteri Hukum dan Hak Asasi Manusia, Oktober 2020, “asimilasi adalah proses pembinaan narapidana dewasa dan anak yang di laksanakan dengan membaurkan narapidana dan anak dalam kehidupan masyarakat, integrasi atau pembebasan

6 Pasal 1 Ayat 6 UU RI No. 6 Tahun 2018 tentang Kekarantinaan Kesehatan

7 Keputusan Menteri Hukum dan HAM Republik Indonesia No. M.HH-19.PK.01.04.04 Tahun 2020 Mengenai Pengeluaran dan Pembebasan Narapidana dan Anak Melalui Asimilasi dan Integrasi Dalam Rangka Pencegahan dan Penanggulangan Penyebaran COVID-19

8 Lihat Pasal 4 Undang-Undang No 39 Tahun 1999 tentang Hak Asasi Manusia besyarat, cuti menjelang bebas dan cuti bersyarat adalah program pembinaan yang mengintregrasikan narapidana dan anak ke dalam kehidupan masyarakat setelah memenuhi persyaratan yang telah di tentukan", sebagaimana yang di atur dalam pasal 1ayat 5 Peraturan Menteri Hukum dan HAM RI No. 10 Tahun 2020. Berdasarkan Pasal 23 Peraturan Menteri hukum dan HAM No 10 Tahun menyatakan "bagi narapidana yang tanggal $2 / 3$ (dua per tiga) masa pidananya dan anak 1/2 (satu per dua) masa pidananya sampai dengan tanggal 31 desember 2020".9 Pembebasan narapidana tidak mencakup semua situasi. Hal ini merupakan pengecualian terhadap keadaan tertentu yang diatur dalam Permenkumham No 10 Tahun 2020, yang mengatur tentang ketentuan asimilasi dan integrasi untuk narapidana dan anak sekaligus mencegah dan menanggulangi COVID-19. Narapidana yang tidak dapat dibebaskan dalam program asimilasi dan integrasi adalah narapidana yang telah melakukan tindak pidana terorisme, korupsi, narkoba, prekursor narkoba, psikotropika, kejahatan terhadap keamanan negara dan kejahatan berat HAM, beserta orang asing.

Berdasarkan uraian latar belakang di atas, maka masalah tersebut dapat dirumuskan sebagai:

1. Apa perbedaan antara Peraturan Menteri Hukum dan HAM No. 10 Tahun 2020 dengan Peraturan Menteri Hukum dan HAM No. 03 Tahun 2018 telah sesuai dengan asas pembinaan dalam undangundang pemasyarakatan?

9 Lihat Pasal 23 Peraturan Menteri Hukum dan HAM RI Nomor 10 Tahun 2020 


\section{METODE PENELITIAN}

Penelitian ini, penulis menggunakan penelitian normatif. Penelitian normatif merupakan metode penelitian yang mencari aturan hukum, asas hukum dan doktrin hukum untuk menjawab pertanyaan hukum yang dihadapi.10 Jenis penelitian yang digunakan pada penelitian ini merupakan penelitian normatif. Menurut Peter Mahfud Marzuki, penelitian hukum digunakan untuk menyelesaikan persoalan hukum yang dihadapinya. Penelitian normatif merupakan suatu metode yang digunakan untuk mengetahui aturan hukum, asas hukum dan doktrin hukum untuk menjawab permasalahan hukum yang dihadapi.11

Dalam penyusunan penelitian ini pendekatan masalah yang digunakan adalah dengan menggunakan pendekatan perundangundangan, artinya metode tersebut digunakan untuk mengkaji dan menganalisis masalah hukum melalui peraturan perundangundangan, prinsip dan sistem yang masih berlaku. Dalam penelitian normatif tentunya harus menggunakan pendekatan perundangundangan, Artinya, peraturan tertulis yang mengatur mengenai norma-norma yang mengikat secara hukum dan bentuk atau peraturan badan negara atau pejabat yang berwenang melalui tata cara yang diatur dalam peraturan perundang-undangan kemudian menjadi fokus dan perhatian. tema dalam penelitian ini12.

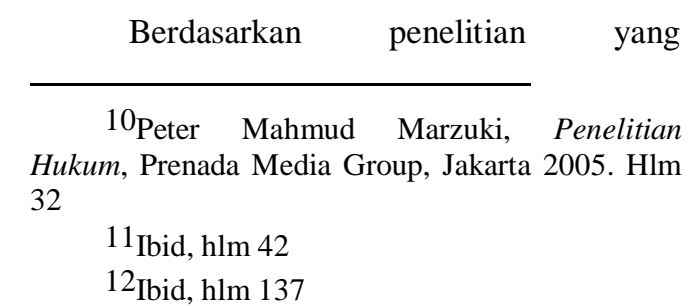

dipaparkan dalam rumusan masalah beserta tujuan yang ingin dicapai, selain pendekatan hukum (Statue Approach) juga terdapat pendekatan konseptual (Conceptual Approach). Menurut Peter Mahmud Marzuki pendekatan konseptual yang berangkat dari Perspektif dan doktrin berkembang dari ilmu hukum. Mempelajari pendekatan konseptual dalam Penelitian ini akan ditemukan ide yang dapat memunculkan konsep hukum terkait dengan permasalahan yang dihadapi. Pemahaman terhadap pandangan para sarjana hukum dan pengembangan doktrin hukum menjadi dasar penelitian dalam membangun argumentasi hukum dalam menyelesaikan permasalahan dalam penelitian ini. 13

\section{PEMBAHASAN}

Analisis Perbandingan Pembebasan Narapidana Dalam Program Asimilasi dan Integrasi

1. Pembebasan Narapidana di tinjau dari Permenkumham No 03 Tahun 2018 tentang syarat dan tata cara pemberian remisi, asimilasi, cuti mengunjungi keluarga, pembebasan bersyarat, cuti menjelang bebas, dan cuti bersyarat

Peraturan Menteri Hukum dan HAM No 3 Tahun 2018 adalah bentuk baru dari perubahan dari Peraturan Menteri Hukum dan HAM No 21 Tahun 2016 mengenai perubahan atas Peraturan Menteri Hukum dan HAM No 21 Tahun 2013 yang sudah di cabut. Narapidana yang akan mendapatkan kebebasan akan kembali lingkungan masyarakat. tetapi sebelum mendapatkan

13 Ibid, hlm 177 
pembebasan narapidana menjalankan pembinaan yang bertujuan mempersiapkan mental dan fisik untuk kembali berbaur di lingkungan masyarakat. Tujuan pembinaan narapidana dalam tahap asimilasi adalah supaya mereka dapat diterima dengan baik di masyarakat.

Asimilasi dalam Pasal 1 angka 4 Peraturan Menteri Hukum dan HAM RI No 03 Tahun 2018 merupakan suatu proses dimana pembinaan narapidana dan anak didik pemasyarakatan yang di lakukan dengan membaurkan narapidana dan anak didik ke masyarakat.14 Berbeda pada Kamus Besar Bahasa Indonesia (KBBI) yang menyatakan asimilasi adalah penyesuaian sifat asli yang dimiliki dengan sifat lingkungan sekitar. Di dalam buku soekanto yang berjudul sosiologi suatu pengantar yaitu:

Asimilasi di definisiskan sebagai Suatu proses yang bertujuan untuk mengurangi perbedaan antara individu atau kelompok, tetapi juga mencakup proses peningkatan kesatuan tindakan, sikap dan proses psikologis, serta memperhatikan kepentingan dan tujuan bersama. Syarat dan tata cara pemberian asimilasi sudah di atur didalam Pasal 44, 45 dan Pasal 50. Namun syarat-syarat lain harus dipenuhi dengan dibuktikan dengan melampirkan dokumen yang di atur dalam Pasal 46 bagi narapidana dan Pasal 49 bagi anak dalam Peraturan Menteri Hukum dan HAM No 3 Tahun 2018. Persyaratan memperoleh asimilasi dapat diklasifikasikan menjadi 2 (dua) dalam

14 Diah Puaspita Rini, implementasi asimilasi kerja sosial terhadap narapidana di tinjau dari Permenkumham No 3 tahun 2018 di lembaga pemasyarakatan kelas 1 Semarang, Universitas Negeri Semarang, 2018, hlm 23
Permenkumham RI No. 3 Tahun 2018 yaitu:

Persyaratan substantif yang harus dipenuhi oleh narapidana adalah sebagai berikut:

1. Narapidana berperilaku baik dengan tidak pernah mendapat hukuman disiplin;

2. Program pembinaan diikuti dengan aktif dan baik oleh narapidana;

3. Telah menjalani $1 / 2$ (satu per dua) masa pidananya;

4. Program pembinaan asimilasi yang akan diberikan pada narapidana dapat diterima oleh masyarakat.

5. Bagi narapidana dengan tindak pidana terorisme harus menyelesaikan Program Deradikalisasi yang diselenggarakan oleh Lapas dan/ atau Badan Nasional Penanggulangan Terorisme dan menyatakan ikrar kesetiaan kepada NKRI bagi Narapidana warga negara Indonesia, sedangkan untuk Narapidana berkewarganegaraan asing berikar untuk tidak melakukan pengulangan tindak pidana terorisme.

Syarat administratif yang harus dipenuhi narapidana, sebagai berikut :

1. Fotokopi berita acara pelaksanaan putusan pengadilan dan kutipan putusan hakim;

2. Bukti pembayaran denda dan uang pengganti sesuai dengan putusan pengadilan;

3. Laporan perkembangan pembinaan yang dibuat oleh wali pemasyarakatan;

4. Laporan Penelitian Kemasyarakatan (Litmas) yang dibuat oleh Pembimbing Kemasyarakatan yang diketahui oleh Kepala Bapas; 
5. Salinan daftar pelanggaran tata tertib narapidana (register F) dari Kepala Lapas;

6. Salinan daftar remisi atau perubahan masa pidana dari Kepala Lapas;

7. Surat pernyataan tidak akan melakukan perbuatan melanggar hukum dan tidak melarikan diri dari Narapidana;

8. Surat jaminan dari keluarga narapidana yang menyatakan untuk membantu membimbing dan mengawasi Narapidana agar tidak melarikan diri dan tidak melakukan perbuatan melanggar hokum, yang diketahui oleh lurah atau kepala desa setempat;

9. Surat keterangan sehat dari dokter atau psikolog;

10. Surat keterangan dari Kepala Lapas dan/atau Kepala Badan Nasional Penanggulangan Terorisme bahwa narapidana yang bersangkutan telah mengikuti Program Deradikalisasi;

11. Bagi Narapidana berkewarganegaraan asing dibutuhkan syarat tambahan, yaitu (a) Surat jaminan dari kedutaan besar/konsulat negara bahwa yang bersangkutan tidak akan melarikan diri dan akan menaati persyaratan yang telah ditentukan; dan (b) Surat keterangan dari Direktur Jenderal Imigrasi atau Pejabat Imigrasi yang ditunjuk, yang menyatakan bahwa yang bersangkutan dibebaskan dari kewajiban memiliki izin tinggal.

Selanjutnya, Syarat dan prosedur pembebasan bersyarat dalam Peraturan Menteri Hukum dan HAM No 3 Tahun 2018 di atur dalam Pasal 82 dan Pasal 83. Syarat lainnya yang wajib dipenuhi narapidana yaitu dengan dibuktikan melampirkan dokumendokumen. Syarat subtantif pembebasan bersyarat adalah :

1. Telah menjalani masa pidana paling singkat $2 / 3$ (dua per tiga), dengan ketentuan 2/3 (dua per tiga) masa pidana tersebut paling sedikit 9 (sembilan) bulan.

2. Berkelakuan baik selama menjalani masa pidana paling singkat 9 (sembilan) bulan terakhir dihitung sebelum tanggal 2/3 (dua per tiga) masa pidana.

3. Telah mengikuti program pembinaan dengan baik, tekun, dan bersemangat, dan

4. Masyarakat dapat menerima program kegiatan pembinaan Narapidana.

Syarat administratif pembebasan bersyarat :

1. Fotokopi kutipan putusan hakim dan berita acara pelaksanaan putusan pengadilan.

2. Laporan perkembangan pembinaan yang ditandatangani oleh Kepala Lapas.

3. Laporan penelitian kemasyarakatan yang dibuat oleh Pembimbing Kemasyarakatan yang diketahui oleh Kepala Bapas.

4. Surat pemberitahuan ke Kejaksaan Negeri tentang rencana pemberian Pembebasan Bersyarat terhadap Narapidana Pemasyarakatan yang bersangkutan.

5. Salinan register F dari Kepala Lapas.

6. Salinan daftar perubahan dari Kepala Lapas. 
7. Surat pernyataan dari Narapidana tidak akan melakukan perbuatan melanggar hukum, dan

8. Surat jaminan kesanggupan dari pihak Keluarga wali, lembaga sosial, instansi pemerintah, instansi swasta, atau Yayasan yang diketahui oleh lurah atau kepala desa atau nama lain yang menyatakan bahwa: Narapidana tidak akan melarikan diri dan/atau tidak melakukan perbuatan melanggar hukum dan membantu dalam membimbing dan mengawasi Narapidana selama mengikuti program Pembebasan Bersyarat.

Selain syarat dan prosedur pemberian pembebasanan asimilasi Peraturan Menteri Hukum dan HAM No 3 Tahun 2018 juga mengatur macam-macam asimilasi yang ada dalam pasal 62 yang berbunyi "Kegiatan pendidikan, Pelatihan keterampilan, Kegiatan kerja sosisal, Pembinaan lainnya di lingkungan masyarakat, dan Asimilasi secara mandiri atau dengan pihak ketiga".

Peraturan Menteri Hukum dan Hak Asasi Manusia No. 3 tahun 2018 memuat peraturan lengkap yang bisa dibilang terkenal, yang mengatur keringanan, asimilasi, cuti keluarga, pembebasan bersyarat, cuti sebelum pembebasan dan cuti bersyarat. Hal tersebut ditujukan tidak hanya tindak pidana biasa saja namun di tujukan bagi narapidana terorisme, narkotika dan prekursor narkotika, psikotropika, korupsi, kejahatan terhadap keamanan negara, kejahatan hak asasi manusia berat, serta kejahatan transnasional terorganisasi laiannya.
2. Pembebasan Narapidana di Tinjau Dari Permenkuham No 10 Tahun 2020 Tentang Pemberian Asimilasi Dan Hak Integrasi Bagi Narapidana Dan Anak Dalam Rangka Pencegahan Dan Penanggulangan Penyebaran Covid 19

Terbentuknya Permenkumham No 10 tahun 2020 yang di sahkan oleh Menteri Hukum dan HAM Yasonna H Laoly dengan pertimbangan "bahwa Lembaga Pemasyarakatan, Lembaga Pembinaan khusus anak dan Rumah Tahanan Negara merupakan sebuah institusi tertutup yang memiliki tingkat hunian tinggi yang rentan terhadap penyerbaran covid 19. Hal tersebut tertuang di dalam Permenkumham No 10 Tahun 2020 pada konsiderans huruf (a)".

Peraturan pemerintah dengan program pemberian asimilasi kepada narapidana telah diklasifikasikan terhadap terpidana tindak pidana biasa atau selain tindak pidana terorisme, narkoba dan prekursor narkoba, psikotropika, korupsi, tindak pidana terhadap keamanan negara dan tindak pidana berat terhadap HAM, serta tindak pidana transnasional terorganisir, orang asing. Permenkumhkam No. 10 Tahun 2020 menetapkan beberapa prasyarat yang harus dilalui oleh setiap narapidana yang akan mendapatkan program pemberian asimilasi tersebut. 15

Kebijakan pelepasan pandemi COVID-19 ditetapkan oleh pemerintah melalui program asimilasi dan undang-undang

15 Fitria ramadhani siregar, pembebasan narapidana ditinjau dari permenkumham RI No 10 tahun2020 sebagai upaya pencegahan covid $19 \mathrm{di}$ indonesia, Riau law journal: vol. 4,no 2, november(2020) 
integrasi. Program asimilasi merupakan proses pembinaan narapidana dan anak melalui integrasi narapidana dan anak dalam masyarakat. Selain itu, hak integrasi merupakan pemberian pelepasan bersyarat, pembebasan bersyarat dan cuti bersyarat kepada narapidana yang melakukan tindak pidana selain terorisme, narkotika dan psikotropika, korupsi, tindak pidana terhadap keamanan negara dan tindak pidana berat terhadap hak asasi manusia, serta tindak pidana transnasional terorganisir. Maupun orang asing. 16

Adapun syarat umum asimilasi bagi narapidana yang tercantum dalam Pasal 2 Permenkuham No 10 Tahun 2020 yang berbunyi:

1. Asimilasi Narapidana dilaksanakan di rumah dengan pembimbingan dan pengawasan Bapas.

2. Narapidana yang dapat diberikan Asimilasi sebagaimana dimaksud pada ayat (1) harus memenuhi syarat:

a. Berkelakuan baik dibuktikan dengan tidak sedang menjalani hukuman disiplin dalam kurun waktu 6 (enam) bulan terakhir;

b. Aktif mengikuti program pembinaan dengan baik; dan

c. Telah menjalani $1 / 2$ (satu per dua) masa pidana.

Sedangkan Persyaratan pembebasan anak melalui asimilasi dirumah berdasarkan Pasal 3 Permenkumham No 10 Tahun 2020 sebagai berikut:

16 Mohamad Anwar, Asimilasi dan Peningkatan Kriminalitas Di Tengah Pembatasan Sosial Berskala Besar Pandemi Corona, Jurnal Buletin Hukum dan Keadilan 4 No. 1 2020, hlm 3
1. Asimilasi anak dilaksanakan di rumah dengan pembimbingan dan pengawas bapas

2. Anak yang dapat di berikan asimilasi sebagaimana dimaksud pada ayat 1 harus memenuhi syarat :

a. Berkelakuan baik yang dibuktikan dengan tidak sedang menjalani hukuman disiplin dalam kurun waktu 3 bulan terakhir

b. Aktif mengikuti program pembinaan dengan baik, dan

c. Telah menjalani masa pidna paling singkat 3 bulan.

Persyaratan mengenai pemberian pembebasan bersyarat dan cuti menjelang bebas dapat diberikan kepada Narapidana, adalah:

a. Telah menjalani masa pidana paling singkat 2/3 (dua per tiga), dengan ketentuan 2/3 (dua per tiga) masa pidana tersebut paling sedikit 9 (sembilan) bulan;

b. Berkelakuan baik selama menjalani masa pidana paling singkat 9 (sembilan) bulan terakhir dihitung sebelum tanggal 2/3 (dua per tiga) masa pidana;

c. Telah mengikuti program pembinaan dengan baik, tekun, dan bersemangat;

d. Masyarakat dapat menerima program kegiatan pembinaan Narapidana.

Pada Pasal 11 Pembebasan bersyarat dapat diberikan kepada anak-anak yang menjalani hukuman kurungan di LPKA yang memenuhi persyaratan: "Telah menjalani masa pidana paling sedikit $1 / 2$ (satu per dua) 
masa pidana dan Berkelakuan baik selama menjalani masa pidana paling singkat 3 (tiga) bulan terakhir dihitung sebelum tanggal $1 / 2$ (satu per dua) masa pidana". Selain ketentuan di atas, kumpulan dokumen lengkap yang harus dipenuhi untuk memberikan asimilasi dan pembebasan bersyarat diatur oleh Pasal 12, yaitu: “fotocopi kutipan putusan hakim dan berita acara pelaksanaan putusan pengadilan,laporan perkembangan pembinaan yang di tanda tangani oleh kepala lembaga pemasyarakatan/LPKA, laporan perkembangan pembinaan di tanda tangani oleh kepala Lapas/LPKA, salinan register $\mathrm{F}$ dari kepala lapas,salinan perubahan darai lapas, serta surat pernyataan dari narapidana atau anak tidak akan mengulangi perbuatan tindak pidana".

Disahkannya Permenkumham No. 10 Tahun 2020 dan Kepmenkumham No. M.HH19.PK.01.04.04 2020 untuk Pembebasan Narapidana dan Anak melalui asimilasi dan integrasi dalam rangka pencegahan dan penanggulangan penyebaran Covid-19 dan Surat Edaran Ditjenpas No. PAS497.PK.01.04.04 dalam kasus yang sama, maka mulai 1 Mei 2020 tercatat kurang lebih dari 40.000 tahanan dikembalikan ke keluarga dan komunitas mereka di bawah kebijakan ini.17 hal tersebut menimbulkan pro kontra dari seluruh masyarakat.

Di dalam "Pasal 18, 19, dan 20 Permenkumham No 10 Tahun 2020 juga mengatur mengenai pertanggung jawaban kepala lapas atas kebenaran, keabsahan, serta kelengkapan dokumen usulan pemberian

17 Fahira Nesya, "Program Asimilasi di Tengah Pandemi: Sebuah Jalan Keluar yang Menjadi Bumerang?" g, Jurnal Biro Komunikasi Anggota 9th Board of PLEADS. pembebasan bersyarat, juga bertanggung jawab atas pembimbingan dan pengawasan narapidana dan anak yang sedang menjalani pembebasan bersyarat. Jika kepala bapas tidak menjalankan tanggung jawab dengan baik maka menteri dapat memberikan sanksi sesuai ketentuan Peraturan Perundang-Undangan”.

Pembebasan pada Permenkumham No 10 Tahun 2020 ini Berlaku bagi narapidana dan anak yang tidak terikat pada PP No. 99 Tahun 2012, ketentuan dan tata cara pelaksanaan hak narapidana yang tidak memberikan subsidi dan bukan warga negara asing. Program pembimbingan diharapkan dapat dijalankan oleh warga binaan dan Mekanisme pengawasan juga dilakukan secara intensif oleh penyuluh masyarakat dengan metode pemantauan terkini melalui media online. Akan tetapi pembebasan narapidana di kondisi wabah covid 19 adalah langkah yang tidak tepat dan hanya bersolusi sementara.

\section{Pembanding Permenkumham No 3 Tahun 2018 dan Permenkumham No 10 Tahun 2020}

Persyaratan asimilasi dan integrasi dalam Peraturan Menteri Hukum dan HAM No 03 Tahun 2018 dan Peraturan Menteri Hukum dan HAM No 10 Tahun 2020 berbeda, yakni terkait tenggang waktu pemberhentian. Dimana "Pasal 23 Permenkumham No 10 Tahun 2020 berbunyi peraturan menteri tersebut berlaku bagi narapidaanan yang tanggal 2/3 masa pidananya dan anak yang tanggal 1//2 masa pidananya saampai dengan tanggal 31 desember 2020".

Berbeda dengan Peraturan Menteri Hukum dan Hak Asasi Manusia Nomor 3 Tahun 2018 yang mencakup seluruh Peraturan 
Menteri Hukum dan HAM Nomor 10 Tahun 2020 hanya berlaku bagi terpidana yang Selain aksi terorisme, narkotika dan prekursor narkotika, psikotropika, korupsi, kejahatan terhadap keamanan negara dan kejahatan berat terhadap hak asasi manusia, serta kejahatan terorganisir yang bersifat transnasional, orang asing.

Dalam Peraturan Menteri Hukum dan HAM No 3 Tahun 2018 menjelaskan bahwa asimilasi dan integrasi diberikan kepada narapidana setelah memenuhi ketentuan substantif dan administratif telah lengkap, namun ada pembeda dengan Peraturan Menteri Hukum dan HAM No 10 Tahun 2020 yang terdapat didalam syarat-syarat pemberian pembebasan asimilasi dan integrasi, baik itu syarat subtantif maupun syarat administratif, sehingga membuat lebih mudah mendapatkan asimilasi dan hak integrasi.

\section{Kesesuaian Permenkumham No. 10 Tahun} 2020 dengan asas pembinaan dalam Undang-Undang pemasyarakatan

Berdasarkan Pasal 1 ayat 3 UndangUndang Nomor 12 Tahun 1995 tentang pemasyarakatan dijelaskan bahwa Lapas merupakan tempat pengembangan dan rehabilitasi narapidana. Dapat dikatakan bahwa pembinaan pemasyarakatan merupakan bagian terakhir dari sistem peradilan pidana dalam sistem peradilan pidana dan merupakan bagian integral dari sistem peradilan pidana yang komprehensif.

Sistem Pemasyarakatan merupakan sistem tata tertib mengenai arah, batasan dan tata cara pengelolaan narapidana berdasarkan Pancasila, dilakukan secara terpadu antara atasan, masyarakat yang diunggulkan dengan peningkatan kualitas narapidana agar sadar akan kesalahan, memperbaiki dan menghindari terulangnya tindak pidana, sehingga dapat berperan aktif. dalam pembangunan dan dapat hidup secara alami sebagai warga negara yang baik dan bertanggung jawab.

Secara umum, sistem pemasyarakatan diterapkan untuk membingkai terpidana menjadi orang-orang seutuhnya yang sadar akan kesalahan dan tidak mengulangi tindak pidana. Petugas pemasyarakatan yang melakukan tugas-tugas yang berkaitan dengan perawatan dan perlindungan narapidana didefinisikan oleh hukum sebagai petugas penegak hukum. Lembaga pemasyarakatan yang lebih efisien diperlukan untuk secara aktif berkontribusi dalam upaya membimbing narapidana di jalan yang benar supaya kembali ke masyarakat. Lembaga Pemasyarakatan sebagai tempat pembinaan bagi narapidana. yang menggunakan bantuan Lembaga Pemasyarakatan hendaknya tidak mengubah fungsinya supaya menjadi narapidana yang tidak terkena tindakan tidak manusiawi.

Kondisi Pandemi covid 19 menjadi sebuah konflik yang sangat mengkhawatirkan seluruh dunia termasuk indonesia, dampaknya membuat resah masyarakat dan menggangu kehidupan dari berbagai aspek. Pandemi Covid-19 (corona virus disease) di indonesia pertama kali menyebar dikalangan masyarakat mulai tanggal 10 maret 2020. Solusi dalam mencegah virus ini adalah tidak berkumpul ditempat yang ramai. Namun solusi ini dapat diterapkan oleh orang-orang yang bebas, dan tidak dengan tahanan dan narapidana. Narapidana yang berada dilembaga 
pemasyarakatan dapat dikatakan kurangnya ruang gerak. Bisa di katakan di dalam lembaga pemasyarakatan di indonesia telah over kapasitas. Overkapasitas menjadi suatu penyebab terjadinya penyebaran covid 19 .

Pada tanggal 30 Maret 2020, Menteri Hukum dan HAM Yasonna H.Laoly mengeluarkan Peraturan Menteri Hukum dan HAM No 10 Tahun 2020 mengenai syarat untuk menjamin hak asimilasi dan integrasi narapidana dan anak dalam rangka pencegahan dan penanggulangan penyebaran COVID-19. Dengan demikian, pemerintah Indonesia membebaskan para narapidana. dengan dua program asimilasi dan integrasi, kurang lebih sekitar 40 ribu tahanan.

Sehubungan dengan hak-hak warga binaan yang ada di atas, penulis tidak akan membahas hak-hak tersebut satu persatu. Ada beberapa sebagian saja yang di bahas yaitu mendapatkan kesempataan berasimilasi dan hak integrasi termasuk cuti mengunjungi keluarga dan mendapatkan pembebasan bersyarat. Tujuan dalam pembebasan narapidana telah di rumuskan dalam pertimbangan konsideran huruf (d) yaitu untuk pencegahan dan penanggulangan penyebaran covid 19. Sedangkan didalam Keputusan Menteri Hukum dan HAM No M.HH19.PK.01.04.04 Tahun 2020 putusan kesatu pengeluaran dan pelepasan narapidana dan anak melalui asimilsi dan integrasi adalah upaya pencegahan dan penyelamatan narapidana dan anak yang berada di lembaga pemasyarakatan, lembaga pembinaan khusus anak, dan rumah tahanan negara dari peneybaran covid 19 .

Berdasarkan "Peraturan Menteri Hukum dan HAM No 10 Tahun 2020 sebagai halnya sama seperti penjelasan yang sebelumnya, ada di dalam pasal 2 ayat 2 mengatur mengenai syarat pemberian asimilasi sebagai berikut:

Narapidana yang dapat diberikan Asimilasi sebagaimana dimaksud pada ayat (1) harus memenuhi syarat:

a. Berkelakuan baik dibuktikan dengan tidak sedang menjalani hukuman disiplin dalam kurun waktu 6 (enam) bulan terakhir;

b. Aktif mengikuti program pembinaan dengan baik; dan

c. Telah menjalani $1 / 2$ (satu per dua) masa pidana".

Perlu di ketahui asimilasi di tuangkan dalam Pasal 36 Undang-Undang No 12 tahun 1995 mengenai Pemasyarakatan bahwa asimilasi di berikan kepada narapidana dan anak pidana (Menurut keputusan pengadilan, seorang anak yang masih anak-anak akan menjadi narapidana di lapas di bawah usia 18 tahun).

Kata pembebasan bersyarat atau pelepasan bersyarat dalam bahasa belanda di sebut voorwaardelijk invrijheids stelling dan dalam bahasa inggris disebut parole.18 Adapun mengenai pembebasan bersyarat di aturpada Peraturan Menteri Hukum dan HAM No 10 Tahun 2020 di rumuskan bertujuan untuk mencegah penularan covid 19. Pembebasan bersyarat diperoleh narapidana dengan memenuhi syarat yang telah di tentukan pada pasal 9, sedangkan tata cara pemeberian pembebasan bersyarat di atur dalam pasal 13-17 dimana dalam pemberian pemebebasan bersyarat di lakukan dengan

18 C Djisman Samosir, Op Cit hlm. 214 
sistem informasi pemasyarakatan yang terintegrasi antara unit pelaksnaan teknis pemasyarakatan dengan kantor wilayah.

Dasar hukum pembebasan bersyarat juga di atur dalm Pasal 15 dan Pasal 16 KUHP, dalam pasal tersebut terdapat syaratsyarat untuk mendapatkan pembebasan bersyarat bagi narapidana.menurut Pasal 15 KUHP yaitu:19

1. Jika terpidana telah menjalani dua pertiga dari lamanya pidana penjara yang dijatuhkan kepada narapidana, sekurang-kurangnya harus sembilan bulan, maka narapidana dapat dikenakan pelepasan bersyarat. Jika terpidana harus menjalani beberapa pidana berturutturut, pidana itu dianggap sebagai satu pidana.

2. Ketika memberikan pelepasan bersyarat, ditentukan pula suatu masa percobaan, serta ditetapkan syarat-syarat yang harus dipenuhi selama masa percobaan.

3. Masa percobaan tersebut lamanya sama dengan sisa waktu pidana penjara yang belum dijalani, ditambah satu tahun. Jika terpidana ada dalam tahanan yang sah, maka waktu tersebut tidak termasuk masa percobaan.

Pasal 16 KUHP yang mengatur tentang pihak yang berwenang untuk menetapkan pemberian pembebasan bersayarat terhadap narapidana yaitu:20

1. Ketentuan pelepasan bersyarat ditetapkan oleh Menteri Kehakiman atas usul atau setelah mendapat kabar dari pengurus

19 R.soesilo, kitap undang-undang hukum pidana, pasal 15, hlm 44 .

20 Ibid hlm 46 penjara tempat terpidana, dan setelah mendapat keterangan dari jaksa tempat asal terpidana. Sebelum menentukan, harus ditanya dahulu pendapat Dewan Reklasering Pusat, yang tugasnya diatur oleh Menteri Kehakiman.

2. Ketentuan mencabut pelepasan bersyarat, begitu juga hal-hal yang tersebut dalam pasal 15a ayat 5, ditetapkan oleh Menteri Kehakiman atas usul atau setelah mendapat kabar dari jaksa tempat asal terpidana. Sebelum memutus, harus ditanya dahulu pendapat Dewan Reklasering Pusat.

3. Selama pelepasan masih dapat dicabut, maka atas perintah jaksa tempat dimana terpidana berada, orang yang dilapaskan bersyarat orang yang dilepaskan bersyarat dapat ditahan guna menjaga ketertiban umum, jika ada sangkaan yang beralasan bahwa terpidana selama masa percobaan telah berbuat hal-hal yang melanggar syarat-syarat tersebut dalam surat pasnya. Jaksa harus segera memberitahukan penahanan tersebut kepada Menteri Kehakiman.

4. Waktu penahanan paling lama enam puluh hari. Jika penahanan disusul dengan penghentian untuk sementara waktu atau pencabutan pelepasan bersyarat, maka terpidana dianggap meneruskan menjalani pidananya mulai dari tahanan.

Menteri Hukum dan HAM mengeluarkan peraturan bertujuan untuk pencegahan dan penanggulangan penyebaran covid 19 untuk narapidana dan anak serta menjamin narapidana dan anak terhindar dari paparan virus tersebut. Namun dalam kenyataannya tidak semua narapidana yang 
kembali kemasyarakat mampu berubah menjadi baik dan tidak mengulangi kejahatan kembali. Keputusan menteri Hukum dan HAM RI No M.HH-19.PK.01.04.04 tahun 2020 ini menyebutkan mengenai pembimbingan dan pengawasanasimilasi dan integrasi dilaksanakan oleh Balai pengawas, dengan laporan pembimbingan dan pengawasan melalui daring.

Pengawasan yang sangat lemah ketika narapidana di kembalikan ke masyarakat melakukan pelanggaran seperti melakukan perbuatan tindak pidana lagi dapat membuat resah masyarakat dan melanggar ketentuan dalam pembebasan bersyarat. Sedangkan di pasal 2 ayat 1 , pasal 3 ayat 1 , pasal 19 Permenkumham No. 10 Tahun 2020 Ditegaskan bahwa peran Bapas mengarahkan dan mengawasi narapidana selama asimilasi dan hak integrasi sangat penting.

Seperti contoh pengingkaran yang dibuat oleh mantan narapidana yang mendapatkan pembebasan asimilasi dan integrasi pada kondisi pandemi covid 19 yaitu: Narapidana yang mendapatkan keputusan bebas dengan program asimilasi dan integrasi di masa pendemi covid 19, tidak semua kembali ke masyarakat dengan untuk berbuat baik justru ada narapidana yang melakukan kejahatan lagi. Dengan kondisi ekonomi yang sulit di karenakan pandemi, sehingga memicu narapidana melakukan tindak pidana lagi. Kementerian hukum dan HAM telah menyiasati bila narapidana melakukan kejahatan dengan menjalankan menejemen resiko berupa pemberlakuan sel pengasingan.21 Kembalinya nara-pidana di lingkungan masyarakat selaian menimbulkan kecemburuan bagai narapidana lain, hal tersebut juga menimbulkan sederet tindak pidana yang di lakukan lagi oleh para narapidana.

Dilain sisi, masyarakat tidak menutup kemungkinan masyarakat justru dibuat resah dengan para narapidana yang telah di bebaskan tetapi tetap saja melakukan kejahatan. Perbuatan yang di lakukan narapidana dii kawatirkan oleh masyarakat akan berulah lagi. Namun pada tanggal 12 mei 2020 telah tercatat ada lebih dari 100 mantan narapidana yang yang di bebaskan melalui asimilasi dan integrasi kembali melakukan tindak pidana, dari jumlah tersebut diantaranya melakukan tindak pidana penganiayaan, pemerkosaan, penyalahgunaan narkotika, pencurian kendaraan bermotor, pencurian dengan kekerasan, penipuan, pembunuhan, perjudian, dan kasus kejahatan lainnya, para mantan narapidana tersebut tersebar dari 19 polda. 22

Upaya pembinaan bagi warga binaan di lembaga pemasyarakatan kurang efektif hal tersebut disebabkan oleh mantan narapidana yang kembali melakukan pelanggaran hukum. Dari berbagai kasus yang terjadi didalam lingkungan masyarakatan hal tersebut menujukan asas pembinaan dalam UndangUndang No 12 tahun 1995 kurang sesuai

${ }^{21}$ Asri Agustin, Kajian Kritis Terhadap Pembebasan Narapidana Dimasa Pandemi Covid 19, fakultas hukum universitas surakarta, hlm 55

${ }^{22} \mathrm{Cnn}$ indonesia.com, "106 napi asimilasi kembali berulah mencuri hingga pencabulan" dikutip dari https://www.cnnindonesia.com/nasional/2020051 2150324-12-502544/106-napi-asimilasi-kembaliberulah-mencuri-hingga-pencabulan (diakses pada tanggal 31 desember 2020) 
dengan Peraturan Menteri Hukum dan HAM No 10 tahun 2020 yang mana asas pembinaan tersebut gagal di terapkan oleh narapidana.

Setelah melakukan pelanggar-an hukum harus dilaksanakan penindakan yang dilakukan dengan cara: meningkatkan pembimbingan dan pembinaan, pencabutan program asimilasi sesuai Surat Edaran Direktur Jendral Pemasyarakatan No PAS-19 516.PK.01.04.06 Tahun 2020 dengan metode : kepala Bapas melakukan pencabutan sementara pelaksanaaan asimilasi atas dasar laporan hasil pengawasan dan pelaporan serta pengusulan deklarasi penarikan asimilasi dengan kalapas dengan melampirkan data pelanggaran dan surat keputusan pembatalan. Selanjutnya kepala lapas menetapkan surat keputusan pencabutan asimilasi, serta kepala bapas melakukan kordinasi dengan kepolisian dan kejaksaan dalam hal pengembalian narapidana. 23

$$
\text { Yang membingungkan dalam }
$$

Permenkumham No 10 Tahun 2020 ini diterapkan segala bentuk pembebasan narapidana dan anak, baik dengan asimilasi ataupun integrasi tidak berlaku bagi narapidana selain tindakan terorisme, narkoba dan prekursor narkoba, psikotropika, korupsi, kejahatan terhadap keamanan negara dan kejahatan berat terhadap hak asasi manusia, serta kejahatan terorganisir internasional, orang asing. Karena pembebasan narapidana tersebut di tujukan untuk kasus pidana umum. Akan tetapi di dalam Pasal 22 Permenkumham No 10 Tahun 2020 menjelaskan Narapidana yang dihukum

${ }^{23}$ Enny Umaroh, Analisis Yuridis Pengawasan Asimilasi dan Integrasi Bagi narapidana dan anak ketika pandemi covid 19, 2020, hlm 10 karena pelanggaran narkoba dan prekursor narkoba, obat psikotropika hanya berlaku untuk mereka yang dihukum penjara hingga 5 tahun.

Permenkumham bisa dikatakan efektif apabila saat dikeluarkan peraturan tersebut tidak hanya mempertimbangkan pencegahan serta penanggulangan covid 19 beserta over kapasitas hunian lembaga pemasyarakatan, tetapi harus mempertimbangkan dampak jika narapidana dibebaskan dalam progam asimilasi dan integrasi. Dalam bukti masih banyak terdapat narapidana yang di bebaskan dengan melalui permenkumham no 10 tahun 2020 yang kembali melakuan tindak pidana, hal tersebut di butuhkan peran pememrintah dalam melakukan pengawasan terhadap mantan narapidana. Pemerintah sangat dibutuhkan dalam memberikan dan menyampaikan ilmu mengenai aturan berperilaku disiplin kepada mantan narapidana yang di bebaskan melalui progra asimilasi dan integrasi.

\section{SIMPULAN}

Pandemi Covid-19 di Indonesia telah mendorong pemerintah membebaskan narapidana dengan mengeluarkan program asimilasi dan integrasi. Dasar hukum pemerintah untuk mengeluarkan narapidana pada saat pandemi Covid 19 adalah melalui Peraturan Menteri Hukum dan HAM No 10 Tahun 2020 perihal persyaratan pemberian hak asimilasi dan integrasi bagi narapidana dan anak dalam rangka penanggulangan dan pencegahan. Hal itu untuk mengatasi penularan covid 19 dilembaga pemasyarakatan. Peraturan Menteri Hukum dan HAM mengatur bahwa asimilasi 
merupakan proses pembinaan narapidana dan anak dengan mengintegrasikan narapidana dan anak kedalam kehidupan masyarakat, sementara itu integrasi adalah suatu pembinaan dengan mengintegrasikan narapidana ke dalam kehidupan masyarakat ketika sudah memenuhi persyaratan yang telah ditentukan.

Berdasarkan hasil uraian di atas, Apa perbedaan antara Peraturan Menteri Hukum dan HAM No. 10 Tahun 2020 dengan Peraturan Menteri Hukum dan HAM No. 03 Tahun 2018 telah sesuai dengan asas pembinaan dalam undang-undang pemasyarakatan ada perbedaan antara pemberian hak asimilasi dan integrasi bagi narapidana dalam Permenkumham Nomor 3 Tahun 2018 diberikan sesuai dengan persyaratan substantif dan administratif secara lengkap. Namun dalam Permenkuham Nomor 10 Tahun 2020 terdapat beberapa perbedaan dalam hal pemberian hak asimilasi dan integrasi, baik persyaratan substantif maupun administratif, sehingga memudahkan narapidana untuk memperoleh hak asimilasi dan integrasi. Seperti didalam Permenkumham No 10 tahun 2020 tidak ada pelaporan penelitian Kemasyarakatan yang dibuat oleh pembimbing Kemasyarakatan yang di ketahui oleh Kepala Bapas.

Menteri Hukum dan HAM melaksanakan asimilasi dan integrasi dalam kondisi pandemi Covid-19 bukanlah kebijakan yang tepat, hal ini mengakibatkan narapidana kembali melakukan tindak pidana dan menimbulkan kekhawatiran yang besar terhadap keamanan masyarakat. Permenkumham Nomor 10 Tahun 2020 belum memenuhi tujuan undang-undang pemasyarakatan karena tidak ada rasa keadilan, kepastian dan kemanfaatan yang dirasakan langsung oleh masyarakat. Dapat dikatakan bahwa sistem pembinaan dan pengawasan kepada narapidana yang dibebaskan dalam program asimilasi dan integrasi kurang tepat. Menyebabkan Lebih dari 100 mantan narapidana yang dibebaskan melalui program asimilasi dan integrasi masih ingkar janji dan kembali melakukan tindak pidana. 


\section{DAFTAR PUSTAKA}

Buku

Atmasasmita, Romli. Sistem Peradilan Pidana (Criminal Justice System) Perspektif Eksistensialisme

Dan

Abolisionalisme. Jakarta. Bina Cipta. 1996.

Achjani Zulfa, Eva dkk. Perkembangan Sitem

Pemidanaan dan Sistem

Pemasyarakatan. Depok. Rajawali

Pers. 2017

Dwijda Priyatno. Sistem Pelaksanaan Pidana

Penjara di Indonesia. Bandung. PT

Refika Aditama. 2013

Ibrahim, Johnny. Teori dan Metodologi

Penelitian Hukum Normatif. Malang.

Bayumedia. 2005

Marzuki, Peter Mahmud. Penelitian Hukum.

Jakarta. Kencana. 2005.

Muladi \& Arief, Barda Nawawi. Teori Teori

dan Kebijakan Pidana. Bandung. 2010

Muladi. Kapita Salekta Sistem Peradilan Pidana. Semarang. 1995

S. Soekanto. Sosiologi Suatu Pengantar. Jakarta. Rajawali Pers. 1990

Soemodiprojo, R. Achmad S. Sistem Pemasyarakatan di Indonesia. Bandung. Bina Aksara. 1989

R. Soesilo. Kitap Undang-Undang Hukum

Pidana. Bogor. Politeia. 1996

Samosir, C.Djisman. Penologi dan Pemasyarakatan. Bandung. Nuansa Aulia. 2016

Peraturan Perudang-undangan

Undang-undang RI No. 39 Tahun 1999 tentang Hak Asasi Manusia
(Lembaran Negara Tahun 2018 No.

Undang-Undang RI No 6 Tahun 2018 tentang

Kekarantinaan Kesehatan (Lembaran

Negara RI No. 3886)

Undang-undang RI No. 12 Tahun 1995

Tentang Pemasyarakatan (Lembaran

Negara RI Tahun 1995 nomor 77,

Tambahan Lembaran RI No. 3614)

Peraturan Menteri Hukum dan HAM Nomor

18 Tahun 2019 Tentang Syarat dan

Tata Cara Pemberian Remisi,

Asimilasi, Cuti Mengunjungi

Keluarga, Pembebasan Bersyarat,

Cuti Menjelang Bebas, Dan Cuti

Bersyarat. Perubahan atas Peraturan

Menteri Hukum dan HAM Nomor 03

Tahun 2018 Tentang Syarat dan Tata

Cara Pemberian Remisi, Asimilasi,

Cuti Mengunjungi Keluarga,

Pembebasan Bersyarat, Cuti

Menjelang Bebas, Dan Cuti

Bersyarat

Peraturan Menteri Hukum dan Hak Asasi Manusia Republik Indonesia Nomor 10 Tahun 2020 Tentang Syarat Pemberian Asimilasi Dan Integrasi Bagi Narapidana Dan Anak Dalam Rangka Pencegahan Dan Penanggulangan Penyebaran COVID-19

Peraturan Menteri Nomor 31 Tahum 1999 Tentang Pembinaan Dan

Pembimbingan Warga Binaan Masyarakat

Keputusan Menteri Hukum dan HAM No. M.HH.-19.PK.01.04.04 Tahun 2020 Tentang Pengeluaran dan Pembebasan Narapidana dan Anak 
Melalui Asimilasi dan Integrasi dalam Rangka Pencegahan dan Penanggulangan Penyebaran COVID-19

Jurnal

Anwar Mohamad. Asimilasi dan Peningkatan Kriminalitas Di Tengah Pembatasan Sosial Berskala Besar Pandemi Corona. Volume 4 No. 1. 2020

Agustiwi Asri. Kajian Kritis Terhadap Pembebasan Narapidana Dimasa Panndemi Covid 19. Surakarta. 2020

Fatah, Muhammad Abdul. Pelaksanaan Hukuman Cambuk Di Dalam Lembaga Pemasyarakatan Di Tinjau Dari Tujuan Pemasyarakatan. Universitas Trunojoyo Madura. Madura. 2020

Moch Agung Bachtiar. Strategi Pembinaan Kemandirian Terhadap Narapidana Residivis Narkotika. Jurnal Ilmu Hukum dan Humaniaro. 2020

Nesya Fahira. Program Asimilasi di Tengah Pandemi: Sebuah Jalan Keluar yang Menjadi Bumerang. Jurnal Biro Komunikasi Anggota 9th Board of PLEADS.

Penny Naluria Utami. Keadilan Bagi Narapidana di Lembaga Pemasyarakatan. Jurnal Hukum de Jure. 2017

Rini Diah Puaspita. Implementasi Asimilasi

Kerja Sosial Terhadap Narapidana di Tinjau Dari Permenkumham No 3 tahun 2018 di Lembaga Pemasyarakatan Kelas 1 Semarang. Universitas Negeri Semarang. Semarang. 2018
Rosidin Utang, Dkk. Kebijakan Asimilasi dan Hak Integrasi Narapidana di Tengah Pandemi COVID-19 Persfektif Hukum Penitensier Universitas Islam Negeri Sunan Gunung Djati. Bandung. 2020

Siregar Fitria ramadhani. Pembebasan Narapidana Ditinjau Dari Permenkumham RI No 10 Tahun2020 Sebagai Upaya Pencegahan Covid 19 Di Indonesia. Riau. Volume 4 No 2. 2020

Suwarto. Pelaksanaan Pidana Penjara dengan Sistem Pemasyarakatan. Jurnal Hukum Pro Justisia. Volume 25 No. 2. 2007

Umaroh, Enny. Analisis Yuridis Pengawasan Asimilasi dan Integrasi Bagi narapidana dan anak ketika pandemi covid 19. 2020

Zulfa Achjani dkk. Perkembangan Sitem Pemidanaan dan Sistem Pemasyarakatan. Depok. Rajawali Pers. 2017

Internet

Kompas.com, "Pembebasan 30.000 Narapidana Akibat Wabah Virus Corona" di kutip dari https://nasional.kompas.com/read/20 20/04/01/09314561/pembebasan30000-narapidana-akibat-wabahvirus-corona (diaksess pada tanggal 03 Juni 2020)

Sistem Data base Pemasyarakatan http://smslap.ditjenpas.go.id/public/g rl/current/monthly (diakses pada tanggal 13 april 2020)

Kemenkumham.go.id, lampung, covid19 asimilasi dan integrasi tata laksana 


\footnotetext{
permenkumham no 10 tahun 2020,

dikutip dari

https://lampung.kemenkumham.go.id

/pusat-informasi/penyuluhan-

hukum/2884-covid-19-asimilasi-dan-

integrasi-tata-laksana-

permenkumham-no-10-tahun-2020

(di akses pada tanggal 6 januari 2021)

Cnn indonesia.com, "106 napi asimilasi kembali berulah mencuri hingga

pencabulan" dikutip dari https://www.cnnindonesia.com/nasio nal/20200512150324-12-

502544/106-napi-asimilasi-kembaliberulah-mencuri-hingga-pencabulan (diakses pada tanggal 31 desember 2020
} 